\title{
SUPPRESSION OF ANNUAL GRASS WEEDS BY AR542 ENDOPHYTE INFECTION IN DRYLAND TALL FESCUE PASTURES
}

\author{
K.N. TOZER, R.J. LUCAS and G.R. EDWARDS \\ Agriculture Group, Agriculture and Life Sciences Division, PO Box 84, Lincoln \\ University, 7647 Lincoln, New Zealand
}

Corresponding author: tozerk@lincoln.ac.nz

\begin{abstract}
The effect of endophyte infection of tall fescue (with and without AR542 endophyte, Neotyphodium coenophialum), plant competition (white versus Caucasian clover, with and without subterranean clover overdrilled) and spring stocking rate (10 versus 20 ewes/ha) on the population size of annual grass weeds was monitored in a pasture on dry, stony soils in Canterbury. Barley grass (Critesion murinum) cover and seedhead production were lower in AR542 than endophyte free pastures and where subterranean clover was overdrilled than where it was not. Vulpia hair grass (Vulpia spp.) seedhead production and cover were lower where subterranean clover was overdrilled and where Caucasian rather than white clover was sown. Ewe stocking rate did not affect annual grass weed cover or seedhead density. The results indicate that sowing tall fescue with AR542 endophyte may be a useful management tool to enhance growth of the perennial grass and reduce invasion of barley grass into dryland pastures.
\end{abstract}

Keywords: barley grass, competition, endophyte, stocking rate, tall fescue, vulpia.

\section{INTRODUCTION}

Annual grass weeds, such as barley grass (Critesion murinum) and vulpia hair grass (Vulpia spp.), are common pasture weeds in summer-dry, seasonally stressed pastures in New Zealand (Bourdôt et al. 2007). They reduce the productivity of high quality pastures, cause animal health problems when seeds penetrate eyes and pelts, and lower wool quality when seeds become entangled in the wool. Chemical herbicides are available for their control, but these can be ineffective (Dowling et al. 1995) and may impact negatively on desirable plant species such as clover. Two alternative approaches to controlling annual grass weeds are the enhancement of plant competition by the use of alternative or improved pasture species and the manipulation of grazing management to reduce seed production and establishment (Hartley et al. 1978; Popay et al. 1981; Bourdôt et al. 2007).

This study examined the effect of spring stocking rate and plant competition on annual grass weed invasion in a tall fescue pasture on a dryland, shallow, stony soil in Canterbury. Tall fescue (Schedonorus phoenix syn. Festuca arundinacea) is more compatible with pasture legumes than perennial ryegrass but is particularly prone to invasion by annual grass weeds (Popay et al. 1981). Recent studies indicate that infection of tall fescue with the non toxic endophyte AR542 (marketed as MAX $\mathrm{P}^{\mathrm{TM}}$ ) may improve tall fescue persistence, productivity and resistance to insect pests relative to nil endophyte tall fescue, without the negative animal health effects associated with wild type endophyte (Popay et al. 2005; Tozer et al. 2007). The hypothesis tested in this study was that AR542 endophyte infected tall fescue, sown with drought tolerant Caucasian clover (Trifolium ambiguum) and subterranean clover (T. subterraneum) rather than white clover (T. repens), and stocked at high stocking rate in spring with ewes, would be the most effective combination for suppressing annual grass weed populations. 


\section{MATERIALS AND METHODS}

\section{Experimental site}

The experiment was conducted in a 4 ha tall fescue-clover pasture at Ashley Dene, the Lincoln University dryland research farm located near Lincoln, New Zealand. The soil type was a Lismore very stony silt loam. Soil tests taken at the start of the experiment gave: $\mathrm{pH}$ (in water) $=6.4$, Olsen $\mathrm{P}=28, \mathrm{Ca}=10$ m.e. $/ 100 \mathrm{~g}, \mathrm{~K}=20$ m.e. $/ 100 \mathrm{~g}$, $\mathrm{Mg}=20$ m.e. $/ 100 \mathrm{~g}, \mathrm{Na}=6$ m.e. $/ 100 \mathrm{~g}$ and $\mathrm{S}=6 \mathrm{~m} . e . / 100 \mathrm{~g}$. Ashley Dene has a mean annual rainfall of $629 \mathrm{~mm}$. Annual rainfall was greater than the long-term average in $2006(945 \mathrm{~mm})$ and less than the long-term average in $2005(501 \mathrm{~mm})$. Of note is that during the differential stocking rate period (spring 2005) August to November rainfall $(80 \mathrm{~mm})$ was less that the average $(90 \mathrm{~mm})$.

\section{Experimental design}

The experiment used four replicates of a $2^{4}$ ( \pm endophyte, two stocking rates, \pm subterranean clover, two perennial clover spp.) factorial laid out in a split block design. Ewe stocking rate (10 or 20 ewes/ha in spring 2005) was the main plot treatment, the factorial combination of endophyte infection (cv. Advance tall fescue sown at $10 \mathrm{~kg} / \mathrm{ha}$ with nil or AR542 endophyte) and perennial clover species (Caucasian clover cv. Endura sown at $8 \mathrm{~kg}$ pelleted seed/ha or white clover cv. Demand sown at $3 \mathrm{~kg}$ bare seed/ha) were the sub plot treatments, and subterranean clover mixture of $5 \mathrm{~kg} / \mathrm{ha} \mathrm{cv}$. Woogenellup and $5 \mathrm{~kg} / \mathrm{ha} \mathrm{cv}$. Karridale (sown or not sown) was the sub-sub plot treatment.

The paddock was cultivated in September 2002, divided into four blocks of 1 ha each. Factorial combinations of endophyte and perennial clover were sown into 0.25 ha plots in each block on 1 October 2002. Microscopic examination of tall fescue tillers in October 2005 (following analine blue staining) showed 63\% of the tillers in the AR542 plots and $0 \%$ of the tillers in the endophyte-free plots were infected with endophyte. The tall fescue pasture that established was sparse with 32 plants $/ \mathrm{m}^{2}$ in mid May 2005. Subterranean clover was overdrilled in $5 \mathrm{~m}$ strips at right angles to the perennial cloverendophyte plots on 17 April 2004. On 22 September 2005, each block was split in half, and one half was allocated to a low stocking rate (10 Coopworth ewes +20 twin lambs set stocked/ha) and one to a high stocking rate (20 Coopworth ewes +40 twin lambs set stocked/ha) for 46 days until 7 November 2005. Outside the experimental stocking rate period, all paddocks were rotationally grazed (4-5 grazing events per year) with Coopworth sheep to a residual pasture mass of 1000 to $1200 \mathrm{~kg} \mathrm{DM} / \mathrm{ha}$.

\section{Measurements}

The percentage cover of all species and of bare ground was recorded in four $0.5 \mathrm{~m}^{2}$ quadrats in each perennial clover plot (two each in areas sown with and without subterranean clover) on 9 August 2006. Seedheads of annual grass weed species were counted in twenty $0.1 \mathrm{~m}^{2}$ quadrats in each perennial clover plot (ten each in areas sown with and without subterranean clover) on 6 November 2006. Data were analysed as an ANOVA of a split block design. All data were transformed before analysis (arcsine square root transformed for percentages and square root for seedhead counts).

\section{RESULTS}

The percentage cover of tall fescue was higher while barley grass and dicotyledonous weeds (mainly storksbill, Erodium spp.) were lower in AR542 than nil endophyte tall fescue (Table 1). There were fewer barley grass seedheads in AR542 than nil endophyte tall fescue. Vulpia cover and seedhead density were lower in Caucasian than white clover. Other grass weeds found in the trial were ryegrass (Lolium spp.) and soft brome (Bromus hordeaceus). Pasture overdrilled with subterranean clover had a lower percentage cover and fewer seedheads of barley grass and vulpia than pasture that was not overdrilled. There was no significant effect of stocking rate on the percentage cover or seedhead density of any species. Annual grass weed cover and seedhead density were unaffected by interactions between endophyte, perennial clover, subterranean clover and stocking rate. 
TABLE 1: Mean plant cover (\% in August 2006) and seedhead production (no. $/ \mathrm{m}^{2}$ in November 2006) for plots with different AR542 endophyte, perennial clover species, subterranean clover and ewe spring stocking rate treatments. Asterisks indicate pairs of means (in bold) that are significantly different at $\mathrm{P}<0.05^{*}$ and $\mathrm{P}<0.01 * *$.

\begin{tabular}{|c|c|c|c|c|c|c|c|c|}
\hline & \multicolumn{2}{|c|}{ Endophyte } & \multicolumn{2}{|c|}{ Perennial clover } & \multicolumn{2}{|c|}{ Subterranean clover } & \multicolumn{2}{|c|}{ Ewes/ha } \\
\hline & None & AR542 & White & Caucasian & None & Sown & 10 & 20 \\
\hline \multicolumn{9}{|l|}{ Percentage cover } \\
\hline Tall fescue & 22.8 & $36.3 * *$ & 26.5 & 32.5 & 32.6 & $26.5 * *$ & 30.8 & 28.3 \\
\hline Perennial clovers & 3.7 & 2.3 & 4.3 & 1.7 & 2.2 & 3.8 & 3.2 & 2.8 \\
\hline Sub clover & 11.0 & 6.3 & 8.7 & 8.7 & 0.0 & $17.3 * *$ & 6.9 & 10.4 \\
\hline Barley grass & 9.6 & $5.1 *$ & 7.6 & 7.1 & 9.3 & $5.4 *$ & 5.8 & 8.9 \\
\hline Vulpia spp. & 7.1 & 5.3 & 10.3 & $2.1^{*}$ & 7.2 & $5.2 *$ & 6.0 & 6.3 \\
\hline Soft brome & 1.9 & 3.3 & 2.8 & 2.3 & 3.0 & 2.1 & 3.2 & 1.9 \\
\hline Dicot weeds & 6.2 & $3.1^{* *}$ & 3.4 & 5.9 & 4.8 & 4.5 & 4.7 & 4.6 \\
\hline Ryegrass & 3.5 & 2.6 & 3.3 & 2.9 & 2.7 & 3.4 & 3.1 & 3.0 \\
\hline Bare ground & 34.2 & 35.8 & 33.2 & 36.9 & 38.3 & $31.8 * *$ & 36.3 & 33.8 \\
\hline \multicolumn{9}{|l|}{ Seedheads $/ \mathrm{m}^{2}$} \\
\hline Barley grass & 139.8 & $45.4 * *$ & 98.4 & 86.9 & 112.4 & $72.8 *$ & 87.2 & 98.1 \\
\hline Vulpia spp. & 168.4 & 204.9 & 265.7 & $107.6^{*}$ & 226.7 & $146.5^{*}$ & 165.6 & 207.8 \\
\hline Soft brome & 39.6 & 28.5 & 39.6 & 28.3 & 37.3 & 30.8 & 38.6 & 29.5 \\
\hline
\end{tabular}

\section{DISCUSSION}

A key result of this study was that infection of tall fescue with AR542 caused a marked suppression of barley grass. The suppression of barley grass is most probably due to the greater competitive effect of tall fescue infected with AR542 endophyte during the peak germination period in autumn and is reflected by the greater percent cover of tall fescue in the AR542 plots. Popay et al. (1981) reported that the use of grass species that are more persistent and productive during summer and autumn (e.g. phalaris (Phalaris aquatica) and cocksfoot (Dactylis glomerata)) may suppress barley grass compared to tall fescue. In an earlier report on the first 2 years of the same experiment as the current study, Tozer et al. (2007) noted that there were more and larger tall fescue plants in the AR542 plots ( 35 plants $/ \mathrm{m}^{2}, 7.5 \mathrm{~cm}$ diameter) than the nil endophyte plots ( $28 \mathrm{plants} / \mathrm{m}^{2}$, $6.8 \mathrm{~cm}$ diameter). These effects were assigned to greater tolerance of insect pests and improved drought tolerance in AR542 infected tall fescue (Popay et al. 2005; Tozer et al. 2007). The increased competitive ability of AR542 endophyte was not due to reduced grazing preference (Edwards et al. 1993) as this did not differ between nil and AR542 tall fescue (Tozer et al. 2007).

A further key result was that overdrilling subterranean clover into sparse tall fescue pasture suppressed both barley grass and vulpia 2.5 years after sowing. It is likely that the effect reflected subterranean clover seedlings pre-empting establishment of some barley grass and vulpia seedlings in autumn, combined with reduced grass weed survival as subterranean clover increased in abundance and became more competitive in early spring. It is unknown whether the effect of subterranean clover on annual grass weeds will persist. Dowling et al. (1995) working in Australian grasslands reported vulpia populations were initially suppressed after subterranean clover oversowing. However, within 2 years vulpia dominated the pastures, particularly in drought prone areas.

The greater suppression of vulpia by Caucasian than white clover is surprising given the negligible differences between white and Caucasian clover in cover (Table 1) and 
growth (Tozer et al. 2007). However, Caucasian clover is more drought tolerant than white clover (Black \& Lucas 2000), most likely because of its deep tap root and superior ability to access moisture. This may enable Caucasian to deprive vulpia of moisture in the shared root zone to a greater extent than white clover and suppress vulpia, especially as vulpia is shallow rooted (Jurjavcic et al. 2002).

Spring stocking rate had no significant effect on annual grass weeds measured a year later in the following spring. Previous work indicated that hard set stocking over a two year period to maintain short but not overgrazed high density ryegrass pasture virtually eliminated barley grass (Hartley et al. 1978; Popay et al. 1981). The lack of stocking rate effect in this study may be due to both stocking rates ( $>10$ ewes/ha) being high during the onset of dry period in spring 2005, so resulting in open pastures the following spring. As an indication of this, Ates et al. (2006) working in the same experiment as this study noted subterranean clover seed production was very low at both high and low stocking rates due to overgrazing.

In summary, infection of tall fescue pastures with AR542 endophyte and overdrilling subterranean clover will not only improve the feeding value and persistence of dryland pastures (Ates et al. 2006; Tozer et al. 2007) but may also aid in the suppression of annual grass weeds. Population ecology studies where weed species are sown into pastures with different endophyte strains and clover species are now underway to identify the mechanisms by which endophyte and subterranean clover overdrilling suppress weeds.

\section{REFERENCES}

Ates S, Brown HE, Lucas RJ, Smith MC, Edwards GR 2006. Effect of ewe stocking rate in spring on subterranean clover persistence and lamb liveweight gain. Proceedings of the New Zealand Grassland Association 68: 95-99.

Black AD, Lucas RJ 2000. Caucasian clover was more productive than white clover in grass mixtures under drought conditions. Proceedings of the New Zealand Grassland Association 62: 183-188.

Bourdôt GW, Fowler SV, Edwards GR, Kriticos DJ, Kean JM, Rahman A, Parsons AJ 2007. Pastoral weeds of New Zealand: status and potential solutions. New Zealand Journal of Agricultural Research 50: 139-161.

Dowling PM, Verbeek B, Lemerle D, Leys AR 1995. Rapid regeneration of vulpia (Vulpia bromoides) in pastures. Proceedings of the 15th Asian-Pacific Weed Science Society Conference. Pp. 497-500.

Edwards GR, Lucas RJ, Johnson MR 1993. Grazing preference for pasture species by sheep is affected by endophyte and nitrogen fertility. Proceedings of the New Zealand Grassland Association 55: 137-141.

Hartley MJ, Atkinson GC, Bimler KH, James TK, Popay AI 1978. Control of barley grass by grazing management. Proceedings of the 31 st New Zealand Weed and Pest Control Conference: 198-200.

Jurjavcic NL, Harrison S, Wolf AT 2002. Abiotic stress, competition, and the distribution of the native annual grass Vulpia microstachys in a mosaic environment. Oecologia 130: 555-562.

Popay AI, Hartley MJ, Crouchley G 1981. The effect of different pasture cultivars on barley grass invasion. Proceedings of the 34th New Zealand Weed and Pest Control Conference: 107-111.

Popay AJ, Jensen JG, Cooper BM 2005. The effect of non-toxic endophytes in tall fescue on two major insect pests. Proceedings of the New Zealand Grassland Association 67: 169-173.

Tozer KN, Ates S, Mapp NR, Smith MC, Lucas RJ, Edwards GR 2007. Effects of $\mathrm{MaxP}^{\mathrm{TM}}$ endophyte in tall fescue on pasture production and composition, and sheep grazing preference, in a dryland environment. Proceedings of the 6th International Symposium on fungal endophytes of grasses. Pp. 259-272. 